\title{
РАСТЕНИЕВОДСТВО
}

DOI: $10.22363 / 2312-797 X-2017-12-2-103-110$

\section{ORGANIC TECHNOLOGY OF TEA PRODUCTION AT BLACK SEA COAST OF KRASNODAR REGION}

\author{
V.D. Nagornyy, V.O. Gresis, M.U. Lyashko \\ Peoples' Friendship University of Russia (RUDN University) \\ Miklukho-Maklay str., 8/9, Moscow, Russia, 117198
}

\begin{abstract}
This paper presents preliminary results of the first try to introduce organic technology of tea leaves production at the resort area on the Black Sea coasts in Krasnodar district. The named technology is introduced on the tea gardens of the firm "Matsetinskyi tea" in 2007. Tea gardens situated on hill slopes which have elevation 350 above the sea level. Experimental plots (three on each of two gardens) were situated $170 \mathrm{~m}$ apart down along the slope of a range of Caucasus mountains. Soil and leaf samples were taken at leaf harvesting time in June 2015. Chemical analysis of soil and leaves were carried out in accordance with recommendations adopted by Georgia Institute of subtropical crops. Tea leaves for analysis and yield on experimental plots were collected five times during the season. Chemical analysis of nutrient content in the leaves, and quality of tea have been done in the analytical laboratory of the Agrotechnological Institute Of PFUR. Preliminary results of experiment revealed rather notable decrease of total yields of leaves in both gardens in comparison with previous yields when mineral fertilizers were applied annually in the rate $\mathrm{N}_{300} \mathrm{P}_{150} \mathrm{~K}_{155}$. Decrease of the yield may be explained by the decrease of nutrient supply due to slow nutrient release by mineralization from trimming materials. Dead leaves, cut weeds and tea bush trimmings, which are the only source of nutrients might be added to the soil. Lower yields at the top of the hills also correlate with lower supply of organic material to the soil on the top of the hills. Thorough analysis has to be done to determine 'for' and 'contra' to organic tea production taking into account loses of yield and gains in cost of production decrease and possible higher price for organic tea. Positive affect of organic technology of tea production on ecology should be also accounted for.
\end{abstract} material

Key words: organic technology, organic tea, resort area, ecology, tea plantation, yield, organic

\section{INTRODUCTION}

Organic crop production is a system of agriculture, based on use of organic material and composts as only source of nutrients for growing crops, and complete refusal of application of mineral fertilizers and plant protection chemicals. According to IFOAM (International Federation of Organic Agriculture Movements), organic management is aiming at a junction of agricultural systems with natural ecosystem's resources, biogeochemical cycles of circulation of elements. "Organic management in the long-term outlook is required to maintain health to objects of agriculture (such us plants, animals, soil, 
people), and as the whole planet" — that is the goal stated by IFOAM. This innovative technology has attracted attention of tea producers at the resort sea shore in Krasnodar district.

In this region, organic management excludes the possibility of the use of high doses of mineral manure, plant protection products and the setting up of enterprises, which may emit bad odors. The International Association of certification of organic products has established the following rules for tea-production's enterprises:

1) the transplanting and cultivation of tea plants without the use of mineral (synthetic) fertilizers and plant protection of inorganic origin;

2) harvesting without disregard of environment;

3) the processing of tea leaves without the use of chemically aggressive products;

4) the use of packaging materials friendly to environment.

Production and consumption of organic products go up from year to year. Pursuing this worldwide trend a private tea company "Matsestinsky tea" near Sochi in 2007 made the switch to the production of tea leaves without the use of mineral fertilizers and plant protection chemicals. After transfer to this technology and after relevant inspection of the tea plantation near Sochi this company has obtained an international certificate ICEA. From the date of transfer to organic technology, comprehensive objective assessment of its advantages or disadvantages were not been carried out. The main positive aspects in a such case more than likely is reduction of the cost of procurement, storage and use mineral fertilizers and chemicals, and as a result decrease of cost of production. Secondly, it might be an improvement of product quality, and inevitably, increase of demand. Negative moments may be the reduction of yields, prolonged periods between harvestings of leaves, and spread of pests and diseases, which can affect the quality of the products. All these pros: and cons of organic production of tea leaves can be estimated based on basis of financial accounting and analysis of all the factors of production: soil fertility, crop yields in plantations, product quality, production costs and selling prices.

\section{OBJECTIVES AND METHODS OF RESEARCH}

The objectives of our study was to investigate the influence of organic technology of growing tea plants on the brown forest soil, and on the yields and quality of tea leaves, to study he dynamics of the basic nutrients content in the soil in relation with the technology used on plots which have different exposition with different degree of slope. The 9-ha gardens were located on the slopes of the Caucasian Range at different elevations above sea level. Assessment of the effect no-fertilizers use and no-application of plant protection products was done by total amount of tea leaves harvested on plots varying in exposure on the gentle slopes of the mountains.

Chemical analysis of soil plant materials on two experimental plots was done by routing and conventional methods in accordance with the relevant state standards. Results of soil analyses (table 1) revealed high soil fertility under tea gardens, what is a main consequence of previous use of high dosages of mineral fertilizers. 
Content of main nutrients is the soils on two experimental plots

\begin{tabular}{|l|c|c|c|c|c|c|c|c|}
\hline $\begin{array}{c}\text { Experimental plot (height, } \\
\text { m above sea level) }\end{array}$ & $\mathrm{pH}$ & $\begin{array}{c}\mathrm{EEC} \\
\mathrm{Meq} \\
100 \mathrm{~g}\end{array}$ & \multirow{2}{*}{$\begin{array}{c}\mathrm{OM}, \\
\%\end{array}$} & \multicolumn{5}{|c|}{ Nutrient content } \\
\cline { 5 - 10 } & & & $\begin{array}{c}\mathrm{N} \% \\
\text { total }\end{array}$ & $\begin{array}{c}\mathrm{N} \mathrm{mg} / \mathrm{kg} \\
\text { mineral }\end{array}$ & $\begin{array}{c}\mathrm{P}_{2} \mathrm{O}_{5} \% \\
\text { total }\end{array}$ & $\begin{array}{c}\mathrm{P}_{2} \mathrm{O}_{5} \\
\mathrm{mg} / \mathrm{kg} \\
\text { available }\end{array}$ & $\begin{array}{c}\mathrm{K}_{2} \mathrm{O} \\
\mathrm{mg} / \mathrm{kg} \\
\mathrm{mobile}\end{array}$ \\
\hline Plot 1 (from 360 to $396 \mathrm{~m}$ ) & 3,8 & 3,83 & 4,6 & 0,73 & 90 & 0,11 & 130 & 240 \\
\hline Plot 2 (from341 to $366 \mathrm{~m}$ ) & 4,0 & 4,10 & 4,2 & 0,6 & 85 & 0,25 & 160 & 310 \\
\hline
\end{tabular}

Pursuing organic technology of tea leaf production one should take into account what kind organic material may by brought to a tea garden to compensate depletion of nutrients and improving physical quality of a soil. Application of any kind manures and other foreign organic material is not acceptable at resort area. The only sources may and are to be different trimmings of tea bushes regularly performed in tea gardens. Three type trimmings are used in tea gardens: light trimming to form desirable form of bushes more appropriate for a given method of leaf harvesting; semi hard trimming and hard trimming. The last one is usually called as 'renovation of a tea garden'. The light type of trimming usually performed every year and may leave about $15-16$ tons of leaves and young branches on one hectare of a tea plantation. Depending on conditions of growth semi hard trimming may be performed in $4-5$ year period. Renovation hard trimming usually performed in 12-15 years. Semi hard trimming may produce around 30 ton of fresh organic material, whereas hard trimming may leave $75-80$ tons per ha $[1 ; 2]$. Thus, organic material left after performing different types of trimming is the main store of nutrients for growing tea bushes. The additional source of organic material may be the application of all by-products of tea leaf processing. So, composition of these materials and its amount determine conditions of mineral nutrient supply into soil.

\section{THE RESULTS OF RESEARCH AND DISCUSSION}

Analysis of chemical composition of leaves, young and old tea bush branches allow us to calculate the balance between nutrient demand of productive tea plants and amount of nutrients may be supplied into soil after each year light formation trimming. The results of these studies are presented in Table 2, 3 and 4 below.

Table 2

\section{Content of mineral nutrients in leaves and young brunches, left on the plantations after light formation trimming}

\begin{tabular}{|l|c|c|c|c|c|}
\hline \multirow{2}{*}{$\begin{array}{c}\text { Experimental plot } \\
\text { (height, } \mathrm{m} \text { above sea level) }\end{array}$} & \multicolumn{4}{|c|}{ Total content in 16 tons of plant material trimmed/ kg/ha } \\
\cline { 2 - 6 } & $\mathrm{N}$ & $\mathrm{P}_{2} \mathrm{O}_{5}$ & $\mathrm{~K}_{2} \mathrm{O}$ & $\mathrm{CaO}$ & $\mathrm{MgO}$ \\
\hline Plot 1 (from 360 to 396 m) & 240 & 132 & 121 & 40 & 52 \\
\hline Plot 2 (from341 to 366 m) & 210 & 130 & 114 & 49 & 46 \\
\hline
\end{tabular}


The average yields of leaves on the tea plantations

\begin{tabular}{|c|l|c|c|c|}
\hline \multirow{2}{*}{$\begin{array}{c}\text { Experimental } \\
\text { plot }\end{array}$} & Exposition & \multirow{2}{*}{$\begin{array}{c}\text { Yield, } \\
\text { t/ha }\end{array}$} & & \multicolumn{2}{|c|}{ Yield, t/ha } \\
\cline { 3 - 3 } & & & $\begin{array}{c}\text { Average yield on garden } \\
\text { under organic technology }\end{array}$ & $\begin{array}{c}\text { Average yield under con- } \\
\text { ventional technology }\end{array}$ \\
\hline \multirow{2}{*}{1} & Top & 3.7 & & 5.2 \\
& Middle & 4.1 & & \\
\cline { 2 - 3 } & Lower & 3.7 & & 4.3 \\
\hline \multirow{2}{*}{2} & Top & 2.9 & & \\
\cline { 2 - 3 } & Middle & 2.9 & & \\
\cline { 2 - 3 } & Lower & 4.6 & & \\
\hline
\end{tabular}

Table 4

Balance of nutrients at average yield of tea leaves $3 t / h a$

\begin{tabular}{|l|c|c|c|r|r|}
\hline \multirow{2}{*}{ Article of balance } & \multicolumn{5}{|c|}{ Total amount of nutrients, $\mathrm{kg} / \mathrm{ha}$} \\
\cline { 2 - 6 } & $\mathrm{N}$ & $\mathrm{P}_{2} \mathrm{O}_{5}$ & $\mathrm{~K}_{2} \mathrm{O}$ & $\mathrm{CaO}$ & $\mathrm{MgO}$ \\
\hline Removal by plants & 103 & 6 & 57 & 7 & 9 \\
\hline Supply with trimming & 240 & 132 & 121 & 40 & 52 \\
\hline Balance & +137 & +126 & +64 & +33 & +45 \\
\hline
\end{tabular}

Thus, under organic technology of tea production major source of nutrients is process of mineralization of organic matter (leaf litter, plenty of weeds cut, and plant materials of trimming and pruning). The obvious result of this study is positive balance between nutrient uptake by plants and nutrient supply with organic material left on a plantation. Although under optimal conditions of humidity and temperature the mineralization process of organic matter is active, but, obviously, the release rate of the fertilizer elements doesn't correspond to the rhythm of uptake of nutrients by plants.

The first and the negative result of the transition to organic technology of production tea-leaf is a reduction in productivity of tea bushes (table 3 ). This is noted in all lots with different exposures and on experimental in total. Depending on exposures productivity of tea bushes decreases down the slope, although on one of the lots productivity of tea plants was higher on the middle plot, which is between upper and lower plot of the same garden. From the data shown in Table 3, it is obvious that the reduction of the yield under organic technology is essential: on the lot No. $1-1.3 \mathrm{t} / \mathrm{ha}$; on the lot No. $2-0.8 \mathrm{t} / \mathrm{ha}$. The amount of organic material left after pruning depends on the productivity of tea-plants; the lower is production on the upper plot, the lower is amount of organic material left on the plot after pruning, and imbalance between supply and demand of nutrients is greater.

The question is: why calculated positive balance of nutrients does not reflects on productivity of tea bushes? Again, why comparatively high dosages of mineral fertilizers used in the past were very so effective? The answer to these questions should be looked for in the speed of nutrient release, mineral translocation in period between active vegetation of tea plants, and possibly in heterogeneity of soil profile in tea gardens.

Application of mineral fertilizers (on average $\mathrm{N}_{300} \mathrm{P}_{150} \mathrm{~K}_{150}$ ) and split application of nitrogen fertilizer under conventional technology provides better availability of nutrient to plants [3]. Apart from this, the same amount of organic material left on the plan- 
tations after pruning always served as an additional source of nutrients for plants. This fact may partially explain the decline of yields of tea leaves on plantations under organic technology of tea production.

The amount of plant material left on the plots after trimming and pruning depends on the type of pruning and frequency of pruning. Forming pruning is conducted each year. And it obvious that nutrient supply in form of fresh organic material conceals and hinders effect of light trimmings performed each year. It is not clear what happens with nutrients released into soil between periods of intensive plant growth in periods from May to September? And how much is lost through leaching and water run-off. More profound studies are needed to find answer to all this questions.

After many years of using pesticides and chemical fertilizers on tea plantation in Krasnodar area ecological balance has changed. Suddenly stop using pesticides and chemical fertilizers on tea plantations could develop unhealthy diversity of natural enemies, soil micro-organisms, and other helpful living things. It may be for this reason, it has been noted that some pests may cause reduction of plant growth. After a few years of introduction of organic technology in a small area it is difficult to expect that tea bushes on experimental plots may look healthier. Bur contrary, quantity of aphids, tea leaf moth, and plant bacteriosis may be a reason of reduction of plant productivity. So, balanced soil fertility and integrated pest management will both become as a part of developing organic technology of tea production. It may be somewhat difficult to achieve but production of better yields in amount and quality of produce require to achieve it.

During transition to organic tea-growing technology, which dictated by the interests of production of better quality organic product, in fact, materials of trimming and pruning is the only source of replenishment of nutrients in the soil. By increasing organic matter content physical quality of soil may be increased too. Diverse and abundant mixture of organisms will create better environment it root zone. As a result, healthier crops and will help reduce pest problems. Mineral fertilizers, as a role, produce negative effect on chemical properties of soil, whereas organic matter improves them. Organic farming ensures that nutrients are not used up more quickly than they can be always made available. Most important that organic technology ensures that the nutrient cycle is completed within the plantations. It requires that all nutrients inputs (trimming and pruned material, weeds, all by-products of tea leaf processing are used on the same soil where they are produced. Above all this is and will be one of the priorities in promoting long-term sustainability. The goal is clear: organic production should produce as much of their own nutrients as possible, to ensure a nutrient cycle that is as self-contained and sustainable as possible.

Results of studies show that yields of good quality leaves may be somewhat lower, mostly because, firstly, of slow release of nutrients from organic materials in period of intensive plant growth, and eventually, lower production of leaves to be harvested. To satisfy the nutrient requirements of the growing plants, especially nitrogen and potassium. Phosphate content is extremely high as a consequence of previous use of phosphate fertilizers in the past. Calcium and magnesium content in gray forest soil is sufficient due to soil formation on sedimentary rocks. Thus, improvement of plant nutrition should be secured by other means than supply of additional organic material. The first 
proposal is to do trimming and pruning of tea bushes early in the spring time, what may help to avoid losses of nutrient through leaching and water run-off.

Pests control may be more difficult to perform in accordance with the rules of organic production. For a while there is no accepted curative tools compared to a farmer who can use synthetic pesticides. Pest management probably will be still too difficult. In tea production areas, insects usually can be kept under control by natural enemies and by good management of the ecosystem, for example, by planting shade trees to manage thrips and red spider mites. Apart from nutritional problem there is a problem of plant protection from aphid, foliar miners, tea-moth, eurygaster bug, and thrips. These insects are present on all old tea gardens. They may appear on organic plantations too. In this case of mechanical leaf harvesting does not guarantee that damaged leaves and insects themselves may be brought to the processing line reducing quality of the leaf tea. Although, some certifying organizations do allow using low-toxicity curative tools, such as disease organisms to control insects, and compost "teas" to control plant diseases.

The market for organic tea is still relatively small, but nevertheless, it is growing. Recent publicity about the health benefits of drinking organic food may increase demand for organic tea, because people drinking tea for their health would probably be interested in organic tea too. Prices for organic tea are generally higher than those for conventional teas. Consumers are willing to pay more for a safer product, but there should be secured guarantee the tea is genuinely produced according to organic standards. The question is obvious: can better quality of products, and, as consequence of it, increase the price offset the decline of productivity of plantations under organic tea production-growing? The answer can be formulated after deep and detailed study of the dynamics of nutrients in the soil under organic technology. It is worth of studding possibility of a partial compensation of the deficit of nutrients in the soil by application of smaller dosages of mineral fertilizers. The answer to all these questions can give be found during further detailed research on the fundamentals of the organic tea production.

\section{CONCLUSION}

1. Organic tea production at Black Sea coast in Krasnodar district may be advantageous given the right time of tea bush trimming and pruning can be found. This will allow achieving better use of nutrients by plant during mineralization of fresh organic materials.

2. Positive balance between nutrient content in organic materials used and nutrient removal by tea plant is the main advantage in organic technology on tea plantation. Realization of this advantage is the matter of good management practices aimed at preventing unproductive losses of nutrients through leaching and water run-off.

3. Decrease of tea leaf yields on tea gardens under organic production is noted in different countries is the recognized fact. There is nothing strange, as soil fertility cannot be increased without replenishment of all nutrients removed by leaves harvested.

4. The sustainability of organic tea production will mainly depend on balance between cost of production and price on organic product at the home and foreign markets. 


\title{
REFERENCES
}

1. Nguen Van Tao. The study of types and time of pruning of selection tea-variety in Abkhazia. Moscow, 1995.

2. Vorontsov, V.V., \& Shteyman, U.G. The cultivation of subtropical crops. Moscow: Kolos, 1982. $362 \mathrm{~s}$.

3. Shteyman, U.G. The effectiveness of the green manuring and nitrogen fertilizer on young teaplantations in the Krasnodar region. Moscow, 1965. 189 s.

DOI: $10.22363 / 2312-797 X-2017-12-2-103-110$

\section{ОРГАНИЧЕСКАЯ ТЕХНОЛОГИЯ ВЫРАЩИВАНИЯ ЧАЯ НА ЧЕРНОМОРСКОМ ПОБЕРЕЖЬЕ КРАСНОДАРСКОГО КРАЯ}

\author{
В.Д. Нагорный, В.О. Гресис, М.У. Ляшко \\ Российский университет дружбы народов \\ ул. Миклухо-Маклая, 8/2, Москва, Россия, 117198
}

В статье представлены предварительные результаты первой попытки использования органической технологии выращивания чая в курортной зоне на Черноморском побережье Краснодарского края. Данная технология начала применяться на чайных плантациях, принадлежащих предприятию «Мацестинский чай», еще в 2007 г. Чайные плантации расположены на прибрежной гряде Кавказских гор с высотой 350 м над уровнем моря. Экспериментальные участки (по три экспозиции на двух плантациях) находились на расстоянии 170 м друг от друга вниз по склону. Образцы почвы и листьев были отобраны во время сбора урожая в июне 2015 г. Химические анализы почвы и чайных листьев были проведены в соответствии с рекомендациями института субтропических культур в Грузии. Сбор чайного листа и учет урожая товарных листьев проведен пять раз в течение сезона. Предварительные результаты эксперимента показали весьма заметное снижение урожайности на обеих плантациях по сравнению с предыдущим опытом, когда применялись минеральные удобрения ежегодно в размере $\mathrm{N}_{300} \mathrm{P}_{150} \mathrm{~K}_{150}$ [3]. Снижение урожайности чайного куста можно объяснить уменьшением содержания питательных веществ в бурой лесной почве, вызванное ограниченным накоплением органического материала (опавшие листья, срезанные сорняки и подрезочный материал с чайных кустов), который является единственным источником питательных элементов, вносимых в почву. Низкая урожайность на верхней экспозиции участка также коррелируется с меньшим внесением органического материала в почву на верхней части склона. Положительный баланс питательных элементов между возможным количеством их в подрезочном материале и выносом урожаем товарных листьев свидетельствует о том, что существует другой «расход» питательных веществ помимо поглощения их растениями. Высказано предположение о значительной потере питательных веществ в осенний, зимний и ранневесенний периоды, когда растения находятся в относительном покое. Предложено продолжить исследования для определения всех «плюсов» и «минусов» органической технологии выращивания чая и экономической оценки органической технологии производства чая при использовании только подрезочного материала.

Ключевые слова: органическая технология, органический чай, курортная зона, экология, питательные вещества, плантации, органический материал

(C) В.Д. Нагорный, В.О. Гресис, М.У. Ляшко, 2017 


\section{БИБЛИОГРАФИЧЕСКИЙ СПИСОК}

1. Нгуен Ван Тао. Изучение видов и сроков подрезки селекционных сортов чая в условиях Абхазии. Москва, 1995.

2. Воронцов В.В., Штейман У.Г. Возделывание субтропических культур. Москва: Колос, 1982. $362 \mathrm{c}$.

3. Штейман У.Г. Эффективность применения сидератов и нитратных удобрений на молодых чайных плантациях в Краснодарском крае. Москва, 1965. 189 с.

\section{Сведения об авторах:}

Нагорный Виктор Дмитриевич - доктор сельскохозяйственных наук, профессор Агробиотехнологического департамента Аграрно-технологического института Российского университета дружбы народов; e-mail: nagvic@yandex.ru

Гресис Валерия Олеговна - магистрант по направлению «Агрономия» Аграрно-технологического института Российского университета дружбы народов; e-mail: gresislera@gmail.com

Ляшко Марина Устимовна - кандидат биологических наук, доцент Агробиотехнологического департамента Аграрно-технологического института Российского университета дружбы народов; e-mail: nagvic@yandex.ru 